\title{
EFFECTS OF SODIUM BICARBONATE SUPPLEMENT ON THE NUTRITIVE VALUE, RUMEN FERMENTATION AND PERFORMANCE OF GROWING FRIESIAN CALVES RATIONS.
}

Ead, H. M. E.

Animal Production Res. Inst., Agric. Res. Center, Dokki, Giza, Egypt.

\begin{abstract}
Twelve 7 month old male Friesian calves with an average body weight of $111 \pm 8.4 \mathrm{~kg}$ were used is this study. Calves were distributed into three groups similar in number. The experimental rations were formulated as follows : ration 1 (R1) $64 \%$ concentrate feed mixture $(\mathrm{CFM})+36 \%$ clover hay $(\mathrm{CH})$ (control), ration 2 (R2) : $64.12 \% \mathrm{CFM}+34.36 \% \mathrm{CH}+1.52 \%$ sodium bicarbonate (SB) and ration 3 (R3) : $60.61 \% \mathrm{CFM}+36.19 \% \mathrm{CH}+3.2 \% \mathrm{SB}$.

The digestibility coefficients of DM, OM, CP, NFE, NDF and ADF and the value of TDN, ME, $(\mathrm{Mj} / \mathrm{kg})$, NE (Mcal / $\mathrm{kg})$, DDM\% and RFV were higher $(\mathrm{p}<0.05)$ for $\mathrm{R} 2$ than $\mathrm{R} 1$ and $\mathrm{R} 3$, while there was no significant difference between $\mathrm{R} 1$ and $\mathrm{R} 3$. The CF and NFC digestibility coefficients were increased $(p<0.05)$ when feeding on $R 2$ compared with $R 1$, while there was no significant difference between $R 1$ and $R 3$ or between $\mathrm{R} 2$ and $\mathrm{R} 3$.

The predicted values for starch and sugar fermentations using CNCPS were (640 and $274 \mathrm{~g} / \mathrm{d}$, respectively) with feeding $\mathrm{R} 1,(475.8$ and $276.8 \mathrm{~g} / \mathrm{d}$, respectively) for R2 and ( 431.7 and $267 \mathrm{~g} / \mathrm{d}$, respectively) for R3 , and the total microbial protein was 815,825 and $775 \mathrm{~g} / \mathrm{d}$ when feeding on R1, R2 and R3, respectively.

The DM intake was increased when feeding on R2 than R1 or R3 because the passage rate was higher when feeding on $\mathrm{R} 2(8.5 \% / \mathrm{h})$ than feeding on $\mathrm{R} 1(7.6 \% / \mathrm{h})$ or R3 $(7.8 \% \mathrm{~g} / \mathrm{h})$.

The mean values for total VFA were higher $(p<0.05)$ with feeding $R 1$ or R2 than R3. The mean values were 9.67, 9.88 and $8.05 \mathrm{ml} \mathrm{eq} / 100 \mathrm{ml} \mathrm{RL}$ for R1, R2 and R3, respectively. The mean values for $\mathrm{NH}_{3}-\mathrm{N}$ concentration decreased $(p<0.05)$ when feeding R2 than R3, but without significant effect with feeding R1. the mean values were 10.96, 9.36 and $13.5 \mathrm{mg} / 100 \mathrm{ml} \mathrm{RL}$ when feeding on $\mathrm{R} 1, \mathrm{R} 2$ and $\mathrm{R} 3$, respectively.

The mean values of blood parameters were not significantly affected by feeding R1 or R2 or R3.

The mean values of ADG were $0.62,0.69$ and $0.66 \mathrm{~kg}$ for steers fed on R1, $\mathrm{R} 2$ and $\mathrm{R} 3$, respectively. Concerning to the amino acids composition of the tested rations, the AAs composition were less than the requirements except for tryptophan. The mean balance AA values (\% of requirement) were $70.45,68.14$ and 71.73 with feeding on R1, R2, R3 , respectively. The production efficiency was lower when feeding on $\mathrm{R} 2$ than feeding on $\mathrm{R} 1$ or $\mathrm{R} 3(16.77,18.74$ and $18.85 \%$ respectively), and the economic efficiency, was also lower when feeding on R2 than feeding on R1 or R3.

In general, the data indicated that feeding ration at a level $64.12 \% \mathrm{CFM}+$ $34.36 \% \mathrm{CH}+1.52 \%$ sodium bicarbonate for growing Friesian calves increased the nutritive values of the ration than using $3.0 \%$ sodium bicarbonate.

Keywords: Friesian steers, sodium bicarbonate, daily gain and economic efficiency.
\end{abstract}


Ead, H. M. E.

\section{INTRODUCTION}

Weaned calves will not eat much feed right after being removed from their dams. Consequently, the feed needs to be very palatable and highly nutritions. Quality is much more important than price when starting calves on feed. A successful ration used is $30 \%$ chopped hay, $18 \%$ soybean meal, 50 $\%$ crashed corn, plus vitamins and minerals (Yohn, 2007). On cattle production operations, a forage diet often will not provide the necessary nutrients to meet the demands of grazing cattle throughout the year (Winger et al, 2006). They found that average daily gain was greater for growing cattle fed supplements of corn and soybean meal, wheat middling or soybean hulls than cattle fed no supplement. As a result, it may be economically advantageous to feed high energy corn based diets when intakes are limited (Loerch et al, 1995). They recommended to feed $4.1 \mathrm{~kg}$ shelled corn (1.3\% of body weight) plus $1.0 \mathrm{~kg}$ per head per day of a $37 \%$ protein supplement. Limit feeding strategies have two potential applications for cattle feeders (Loerch, 1995). The some feeding systems limit intake of a high grain diet to achieve any desired rate of gain. This strategy should be considered when corn is a less expensive source of energy than hay. Growing cattle, such as calves can be safely fed up to 2.0 to $2.25 \%$ of their weight concentrates. Roughage should be given at 1.8 to $2.2 \mathrm{~kg}$ as hay daily (Schreder, 2002). In ruminants, acidosis is defined as the biochemical and physiological stresses by rapid production and absorption of (volatile fatty acids VFA and lactic acid) which arise from the over consumption of readily fermentable carbohydrates (RFC) (Britton and Stock,1986). Heat and pressure processing of RFC as steam flaking, rolling or propping can increase starch availability for fermentability, which in turn increase the propensity for acidosis (Owens et al, 1998). In forage fed animals, ruminal $\mathrm{pH}$ is generally near neutrality $(\mathrm{pH} 7.0)$ and as well buffered by bicarbonate and phosphate from saliva, protein, and forage walls (Russell and Hino, 1985). Normally, when grain is added to ruminant diets, luminal protozoa adapt by increasing their numbers and adequately removing the additional starch (Mackie et al., 1978). However, if the grain levels ingested exceed protozoal capacity to remove starch, protozoa population will decline (Hristov et al., 2001), a drastic increase in bacterial count will occur, fermentation to VFA and Lactic acid will proceed and luminal $\mathrm{pH}$ will decline.

Buffer supplementation of high concentrate diets has been shown to improve or stabilize food intake and increase animal performance in some studies (Zinn, 1991), but not in others (Ghorbani et al., 1989).

One of the best management strategies for reducing foodcosts and improving grain utilization is the use of food additives. Buffers are sometimes used to modulate $\mathrm{pH}$ changes in the lumen (Stock and Modes, 1985). Buffers can be used when adapting cattle to high grain diets and when feeding concentrates such as wheat at high levels. Various buffering agents include sodium bicarbonate, limestone, sodium bentonite and magnesium oxide. Sodium bicarbonate (SB) and limestone can be fed at about $1 \%$ of the diet dry matter. 
Sodium bicarbonate was provided either free choice or mixed into total mixed ration the (TMR) in an attempt to minimize subacute luminal acidosis. For cattle receiving SB as part of the TMR, the supplementation rate was within the recommended range of 0.6 to $0.8 \%$ of DMI (NRC, 2001). When SB was offered free choice, the Jersey steers consumed SB free choice at levels $(129.1 \mathrm{~g} / \mathrm{d})$ that exceeded NRC, (2001) recommendation (Paton, 2005). Hart and Polan (1984) reported for calves fed a corn based diet with added SB ( $1.5,3.0$ and $4.5 \%$ of DM), ruminal $\mathrm{pH}$ was not effected. Similarly, Russell et al (1980) reported luminal $\mathrm{pH}$ of steers fed a finishing diet based on corn supplemented with $0.9 \% \mathrm{SB}$ averaged 6.5 and did not differ from control.

The utilization of sodium bicarbonate has been reported to result in increases in digestibility, rate of passage and in changes in the proportion of VFA (Hart and Doyle, 1985). It has also been suggested that it may improve the amount and efficiency of ruminal microbial protein synthesis, which occurs independently of changes in ruminal fluid dilution rates (Mees et al, 1985), and enhance bacterial uptake of $\mathrm{NH}_{3}$ (Newbold et al, 1988), these effects being eventually associated to a higher feed intake and a subsequent increased daily gain (Tripathi et al, 2004).

Therefore, this experiment was conducted to study the effects of supplementing different levels of sodium bicarbonate in growing Friesiam calves rations on nutrient digestibility, ruminal fermentation and performance.

\section{MATERIALS AND METHODS}

This study was conducted at El-Karada Animal Production Research Station, Animal Production Research Institute, Agricultural Research Center, Ministry of Agriculture, Egypt.

\section{Experimental animals:}

Twelve male Friesian steers, were distributed into three similar groups (Four for each) according to live body weight. The average live body weight was $111 \pm 8.4 \mathrm{~kg}$ and 7 month of age. The animal of each group were housed in a well-ventilated pens. The animals of each group were weighed individually at the morning before morning feeding every four weeks throughout the experimental feeding period, which lasted 6 months (from 7 to 13 months of age). rations.

The groups were assigned at random to receive the three experimental

The experimental rations were formulated as follows:

R1: ration 1: $64 \%$ concentrate feed mixture (CFM) $+36 \%$ clover hay $(\mathrm{CH})$ (as a control ration).

R 2: ration $2: 64.12 \% \mathrm{CFM}+34.36 \% \mathrm{CH}+1.52 \%$ sodium bicarbonate (SB)

R 3: ration 3: $60.61 \% \mathrm{CFM}+36.19 \% \mathrm{CH}+3.20 \% \mathrm{SB}$.

The calculated CP concentration of tested rations ranged from 16 to $16.6 \%$ according to Hunter et al (1999). Calves were individually fed the experimental rations. Animals were fed to cover the requirements of growing calves (Ghoneim, 1967) and were adjusted monthly according to their body weight changes. 
Ead, H. M. E.

The concentrate feed mixture (CFM) used contained $44 \%$ yellow corn , $23 \%$ soybean meal (44\% protein), $14 \%$ wheat bran, $11.5 \%$ rice bran , $4.5 \%$ molasses, $2 \%$, limestone and $1 \%$ salt.

The clover hay was made from the $3^{\text {rd }}$ cut of Egyptian clover.

Management of feeding:

The intake from tested rations by calves were fixed to satisfy their maintenance and production requirements (Ghoneim, 1967) at similar roughage: concentrate ratio. The offered amount was adjusted according to the change in their live body weight at the beginning of each period (4 week intervals). The offered amount of feed on dry matter basis was calculated to be $3.0 \%$ of the live body weight of each group.

The CFM fed with or without SB and was offered to calves at morning. While clover hay $(\mathrm{CH})$ was given after consumption of the concentrate. Drinking fresh and clean water was available at all times.

Digestibility trails:

After about 5 months of experimental feeding period, three digestibility trials were conducted using three animals chosen randomly from each group to determine nutrients digestibility coefficients and nutritive values of the experimental rations.

Acid insoluble ash (AIA) was used as a natural marker Nan Keulen and Young, 1977). Fecal samples were grabbed from the rectum of each animal twice daily for 5 successive days. Nutrients digestibility was calculated from the equations stated by Schneider and Flatt (1975).

Chemical analysis:

Samples of CFM and $\mathrm{CH}$, were taken at the beginning of the trials and every 4 weeks and composited. The composite samples were dried in a forced air oven at $65^{\circ} \mathrm{C}$ for 48 hours, then ground for running the chemical analysis for each. Feces samples were taken from the rectum of each calve twice daily with 12 hours interval during the collection period and dried in a forced air oven at $65^{\circ} \mathrm{C}$ for 48 hours. Dried samples were composted for each animal and representative samples were taken, ground and kept for chemical analysis.

Chemical analysis of CFM, CH and feces were carried out according to the methods of AOAC (1990), Fiber fractions (NDF,ADF ADL, hemc. and cell.) was determined according to method of Van Soset, (1982).

At the end of each collection period ruminal fluid samples were taken using rubber stomach tube before offering the morning feed and at 2, 4 and 8 hrs post- feeding from three animals in each treatment. The collected rumen fluid samples were filtered through three layers of gauze without squeezing for the determination of $\mathrm{pH}$, buffering capacity (BC), ammonia- $\mathrm{N}$ and total volatile fatty acids (TVFA's) concentration. Ruminal $\mathrm{pH}$ was immediately estimated by $\mathrm{pH}$ meter (Orion Research, model 201 digital pH meter). Buffering capacity is the milli-equivelaents of $\mathrm{HCl}$ required to bring the $\mathrm{pH}$ of $100 \mathrm{ml}$ rumen liquor to $\mathrm{pH} 4.5$ (Nickolson et al, 1963) was determined immediately after sampling. Ruminal $\mathrm{NH}_{3}-\mathrm{N}$ was determined according to Conway (1957). Ammonia- $\mathrm{N}$ is released under alkaline conditions from the outer chamber of the Conway plate, absorbed by the boric acid in the center unit and then titrated after $24 \mathrm{hrs}$ using $0.01 \mathrm{~N}$ sulfuric acid. The TVFA's were 
determined by the steam distillation method as described by Warner (1964).After acidification of rumen liquor samples using concentrated orthrophosphoric acid and $0.1 \mathrm{~N}$ hydrochloric acid (HCL), the volatile fatty acids were determined by steam distillation method by using the Kjeldahl apparatus.Distilate was collected within 7 to 10 minutes. The concentration of the amount of $0.01 \mathrm{~N} \mathrm{NaOH}$ needed to neutralize the VFA in the distillate.

Blood samples were taken from each animal individually during the experimental periods of the tested rations. These samples were taken at 3 hrs post-feeding from jugular vein. Blood samples were immediately separated by centrifugation at 4000 r. p. m. for 10 minutes. The serum samples were stored at $\left(-20^{\circ} \mathrm{C}\right)$ until analyses were done. The analysis included total protein (Gornall et al, 1949), albumin, (Hill and Wells, 1983); globulin, (calculated by differences between the total protein and albumin concentrations), urea, (Patton and Crouch, 1977); creatinine, (Ullmann, 1976), Glucose, (Teuscher and Richterich, 1971), GOT and GPT, (Reitman and Frankel, 1957).

Production efficiency:

The ME can be concerted to an NEm requirement with an efficiency of 0.576 (NRC, 1996), and NEp will equal (ME-NEm).

The retained energy $(\mathrm{RE}, \mathrm{Mcal} / \mathrm{d})=\left(\right.$ live weight $\left.{ }^{0.2955} \times 0.544\right) \times(\mathrm{ADG})^{1.262}$

Where ADG is in kilograms (Overton, 1999).

Production efficiency $=\mathrm{RE} / \mathrm{NE}_{\mathrm{p}} \times 100$

Economic efficiency :

Economic efficiency was calculated according to the following formula:

Economic efficiency $=$ (price of daily gain - daily feed cost $)$

The nutritive analysis:

Daily feed cost

The mechanistive sub models as published by Russell et al (1992);

Snieffen et al (1992), O'Connor et al (1992) and Pitt et al (1996) was applied on the experimental rations to predict microbial growth from their carbohydrate and protein fractions and their digestion and passage rate using the net carbohydrate and protein system (CNCPS) programme version 3.0.

\section{Statistical analysis:}

The statistical analysis was performed using the least squares method described by Likelihood programmer of SAS (1994). The obtained data for nutrients digestibility, nutritive value, effective NDF (eNDF) and blood parameters, were subjected to one way analysis of variance according to the following model:

Where:

$$
Y_{i j}=\mu+T_{i}+e_{i j}
$$

$\mathrm{Y}=$ Observation of the tested factor

$\mu=$ Overall mean

$\mathrm{T}_{\mathrm{i}}=$ Treatment effect

$\mathrm{e}_{\mathrm{ij}}=$ Error

The data of rumen liquor parameters were subjected to way analysis of variance according to the following model:

$$
Y_{i j k}=\mu+T_{i}+p_{j}+t p_{i j}+e_{i j k}
$$


Ead, H. M. E.

Where :

$\mathrm{Y}=$ Observation of the tested factor

$\mu=$ Overall mean

$T_{i}=$ Treatment effect

$\mathrm{p}_{\mathrm{i}}=$ time effect

$\mathrm{tp}_{\mathrm{ij}}=$ interaction effect of the treatment ) $\times$ time

$\mathrm{e}_{\mathrm{ij}}=$ Error

The differences among means were carried out according to Duncan's New Multiple Range Test (Duncan, 1955).

\section{RESULTS AND DISCUSSION}

The chemical composition of the ingredients and experimental rations:

The chemical composition of concentrate feed mixture, clover hay $(\mathrm{CH})$ and the total mixed rations are detailed in table (1). The CF , NDF , $A D F$, cellulose and ADL were higher in CH than CFM , while the NFE and NFC were higher in CFM than $\mathrm{CH}$. The CP was similar in both.

The summative analysis of the tested ingredients used to formulate the experimental rations were presented and discussed by Ead and Maklad, (2006).

The total mixed rations for early weaned contain about $16 \%$ protein. In the present study, the three experimental rations were formulated at the commonly, practiced ratio being:

R1 (control): $64 \% \mathrm{CFM}+36 \% \mathrm{CH}$

$\mathrm{R} 2: 64.12 \% \mathrm{CFM}+36.36 \% \mathrm{CH}+1.52 \%$ sodiumbicorbonate (SB).

$\mathrm{R} 3: 60.61 \% \mathrm{CFM}+36.19 \% \mathrm{CH}+3.20 \% \mathrm{SB}$.

These proportions were chosen to achieve is nutrients diets containing about $16 \% \mathrm{CP}, 44 \%$ NDF and $27 \%$ NFC. The NDF / NFC was about 1.6.

There are two main types of carbohydrates. The first is fiber (roughage), and the second is starch and sugars (concentrate). The most common fiber source is hay, which is also rich in other nutrients. Sugars and starch in concentrates provide high amounts of energy. Concentrates are the grains (corn, barley and oats) that make up animal's feed. They are also good sources of vitamins, protein and minerals. Although concentrates provide a readily available source of energy, too much concentrate without enough fiber can throw animal's digestive system out of balance and cause acidosis (Burrell, 2000). Hay quality (fair) contains $14-16 \% \mathrm{CP}, 47-53 \%$ NDF and 36 - $40 \%$ ADF (NRC, 2001).

These observations are in agreement with the results of The present study for the chemical composition of the tested ingredients and formulation of total mixed rations offered to calves during the trial as shown in Table (1).

Dietary fiber levels (neutral and acid detergent fibers) increased while available energy deceased as roughage in the diet increased form 8 to $32 \%$ (Schreder, 2002). Two needs must be considered when formulating the protein requirements of growing cattle. One is the requirement of the host animal for metabolizable protein (amino acids) and the second is the requirement of the microorganisms for available nitrogen in the rumen. If 
metebolizable protein is inadequate, growth of the animal will be limited. If nitrogen available to the microorganisms is inadequate, growth of the microbes will be reduced, presumably limiting digestion in the rumen and reducing the supply of metablizable protein form the microorganisms (Trenkle and Barrett , 2003). Hay without any supplemental feed will not work for early weaned calves (Yohn, 2007). Calves will no gain enough weight to justify early weaning. Calves that are early weaned can be fed a typical high grain feedlot rations . Ration for calves that are early weaned should contain $70 \%$ or greater TDN and 16 to $18 \%$ protein. Calves should consume 3 to $3.5 \%$ of $\mathrm{BW}$ of this ration once they are adapted to the diet. The association between fiber and non-structural carbohydrate (NSC) is a complicated and dynamic relationship (Hoover and Stokes, 1991). Therefore a balance of these two components is necessary to achieve stable fermentation in the rumen. Poor et al (1993) investigated the effect of the ratio of forage NDF to ruminally degradable starch (FNDF : RDS). They proposed that an NDF : RDS ratio of at least 1 .

Table (1): The chemical composition of the ingredients and experimental rations :

\begin{tabular}{|c|c|c|c|c|c|c|c|c|c|c|c|c|c|}
\hline \multirow{2}{*}{ Item } & \multirow{2}{*}{ DM } & \multicolumn{12}{|c|}{ Chemical composition ( \% as DM ) } \\
\hline & & OM & $\mathbf{C P}$ & EE & CF & NFE & Ash & NDF & ADF & Heni & Cell & ADL & NFC \\
\hline $\begin{array}{l}\text { Concentrate } \\
\text { feed mixture } \\
\text { (CFM) }\end{array}$ & 90.86 & 93.07 & 16.54 & 2.14 & 15.17 & 759.22 & 6.93 & 40.34 & 17.58 & 22.76 & 10.00 & 7.58 & 34.05 \\
\hline $\begin{array}{c}\text { Clover hay } \\
(\mathrm{CH})\end{array}$ & 88.89 & 87.71 & 16.61 & 2.29 & 27.76 & 41.03 & 12.29 & 53.29 & 29.58 & 23.74 & 13.96 & 15.62 & 15.52 \\
\hline \multicolumn{14}{|c|}{ Experimental rations (calculated): } \\
\hline R1 & 88.44 & 91.15 & 16.57 & 2.20 & 19.70 & 52.68 & 8.85 & 45.01 & 21.90 & 23.11 & 11.43 & 10.4 & 27.37 \\
\hline $\mathrm{R} 2$ & 88.49 & 89.80 & 16.31 & 2.16 & 19.26 & 52.07 & 10.2 & 44.17 & 21.43 & 22.74 & 11.21 & 10.22 & 27.16 \\
\hline R3 & & & & & & 5075 & 11.84 & 137 & & 22.3 & & & 26.25 \\
\hline
\end{tabular}

R1 : $64 \%$ CFM + $36 \%$ CH

R $2: 64.12 \% \mathrm{CFM}+34.36 \% \mathrm{CH}+1.52 \%$ sodium bicarbonate (SB )

R $3: 60.61 \%$ CFM $+36.19 \% \mathrm{CH}+3.20 \%$ SB

* Non fiberous carbohydrates\%= OM\% - (CP\%+NDF\%+EE\%), (Calsamiglia et al., 1995).

The average daily dry matter intake during the digestion trials :

Data in table (2) showed that the daily DM intake form CFM was 4.84, 5.46 and $4.54 \mathrm{~kg} / \mathrm{h} / \mathrm{d}$ for $\mathrm{R} 1, \mathrm{R} 2, \mathrm{R} 3$, respectively, while the corresponding DM intake form $\mathrm{CH}$ was $2.71 \mathrm{~kg} / \mathrm{h}$. The supplements SB were 0.12 and $0.24 \mathrm{~kg} / \mathrm{h} / \mathrm{d}$ for R2and $\mathrm{R} 3$ respectively. The total DM intake was $2.83,3.18$ and $2.83 \%$ of $B W$ for $R 1, R 2, R 3$, respectively, while the average BW was 266,260 and $264 \mathrm{~kg}$ in experiments R1, R2, and R3, respectively .

\section{Nutrient digestabilities and feeding values of tested rations:}

Table (3) shows the nutrient digestion coefficients and feeding values of tested rations. The digestibility of DM , OM , CP , NFE, NDF, ADF , TDN, $\mathrm{ME}(\mathrm{Mj} / \mathrm{kg}), \mathrm{NE}(\mathrm{Mcal} / \mathrm{kg}), \mathrm{DDM} \%$ and RFV were higher $(\mathrm{P}<0.05)$ for R2 than R1 and R3, while there was no significant difference between R1, and R3. 
Ead, H. M. E.

Table (2): Average daily dry matter intake of concentrate, clover hay and sodium bicarbonate by Friesian calves during the digestion trials:

\begin{tabular}{|c|c|c|c|}
\hline \begin{tabular}{|c|} 
Items' \\
\end{tabular} & $\mathbf{R}$ & 'R2 & R3 \\
\hline Average body weight (kg) & 266 & 260 & 264 \\
\hline Concentrate : Roughage :SB & $64.1: 35.9$ & $65.8: 32.7: 1.5$ & $60.6: 36.2: 3.2$ \\
\hline Intake of DM from : & & & \\
\hline \multicolumn{4}{|c|}{ Concentrate feed mixture (CFM ) } \\
\hline $\mathrm{Kg} / \mathrm{h} / \mathrm{d}$ & 4.84 & 5.46 & 4.54 \\
\hline AS \% BW & 1.82 & 1.96 & 1.72 \\
\hline \multicolumn{4}{|l|}{ Clover hay $(\mathrm{CH})$} \\
\hline $\mathrm{Kg} / \mathrm{h} / \mathrm{d}$ & 2.71 & 2.71 & 2.71 \\
\hline AS \% BW & 1.02 & 1.05 & 1.02 \\
\hline \multicolumn{4}{|l|}{ Sodium bicarbonate (SB) } \\
\hline $\mathrm{Kg} / \mathrm{h} / \mathrm{d}$ & - & 0.12 & 0.24 \\
\hline AS \% BW & - & 0.05 & 0.09 \\
\hline \multicolumn{4}{|l|}{ Total DM intake } \\
\hline $\mathrm{Kg} / \mathrm{h} / \mathrm{d}$ & 7.55 & 8.29 & 7.49 \\
\hline AS $\%$ BW & 2.83 & 3.18 & 2.83 \\
\hline
\end{tabular}

Table (3): Effect of feeding the experimental rations on the digestion coefficients and feeding values by Friesian calves:

\begin{tabular}{|c|c|c|c|c|c|}
\hline Items & R 1 & R 2 & R 3 & \pm SEM & $P$ \\
\hline DM & $83.06^{b}$ & $87.82^{a}$ & $84.33^{b}$ & 0.452 & 0.0008 \\
\hline $\mathrm{OM}$ & $84.05^{b}$ & $90.72^{a}$ & $86.22^{b}$ & 0.729 & 0.0018 \\
\hline $\mathrm{CP}$ & $82.26^{\mathrm{b}}$ & $87.12^{a}$ & $83.45^{b}$ & 0.449 & 0.0006 \\
\hline $\mathrm{EE}$ & 92.64 & 91.58 & 91.41 & 2.443 & 0.9290 \\
\hline $\mathrm{CF}$ & $82.51^{\mathrm{b}}$ & $90.81^{a}$ & $87.20^{\text {ab }}$ & 2.148 & 0.0877 \\
\hline NFE & $83.53^{b}$ & $90.39^{a}$ & $85.64^{b}$ & 0.765 & 0.0019 \\
\hline NDF & $84.53^{b}$ & $88.79^{a}$ & $85.97^{b}$ & 0.619 & 0.0076 \\
\hline ADF & $74.62^{b}$ & $83.81^{a}$ & $77.36^{b}$ & 0.900 & 0.0010 \\
\hline Hemicelluloses & 93.93 & 93.49 & 94.19 & 0.967 & 0.8784 \\
\hline Cellulose & 97.62 & 98.73 & 96.43 & 1.227 & 0.4621 \\
\hline ADL & $49.50^{c}$ & $67.43^{a}$ & $56.68^{b}$ & 1.569 & 0.0006 \\
\hline NFC & $81.35^{b}$ & $93.33^{a}$ & $86.23^{\mathrm{ab}}$ & 2.501 & 2.0377 \\
\hline \multicolumn{6}{|c|}{ Feeding value ( \%) } \\
\hline TDN & $78.46^{b}$ & $83.23^{a}$ & $77.99^{b}$ & 0.557 & 0.0010 \\
\hline $\mathrm{DCP}$ & $13.60^{b}$ & $14.21^{a}$ & $13.38^{\mathrm{b}}$ & 0.067 & 0.0003 \\
\hline $\mathrm{ME}(\mathrm{MJ} / \mathrm{Kg})$ & $11.68^{b}$ & $12.39^{a}$ & $11.61^{\mathrm{b}}$ & 0.083 & 0.0010 \\
\hline ME (Mcal / kg) & $2.79^{b}$ & $2.96^{a}$ & $2.77^{b}$ & 0.019 & 0.0010 \\
\hline${ }^{\star} \mathrm{NE}$ (Mcal / kg) & $1.80^{\mathrm{b}}$ & $1.92^{\mathrm{a}}$ & $1.79^{\mathrm{b}}$ & 0.012 & 0.0007 \\
\hline${ }^{\star \star} \mathrm{DDM} \%$ & $73.46^{b}$ & $77.71^{\mathrm{a}}$ & $74.68^{b}$ & 0.403 & 0.0008 \\
\hline${ }^{\star \star *} \mathrm{RFV}$ & $161.53^{b}$ & $184.36^{\mathrm{a}}$ & $163.96^{b}$ & 4.263 & 0.0170 \\
\hline \multicolumn{6}{|c|}{ 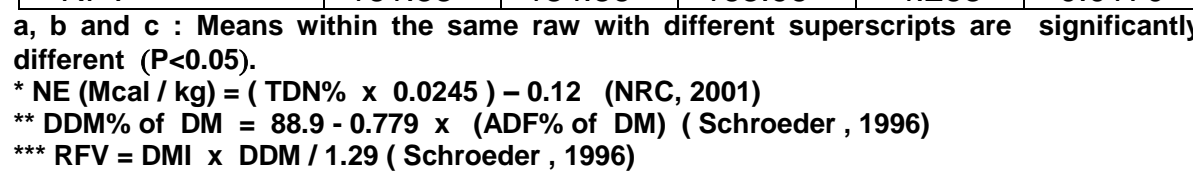 } \\
\hline
\end{tabular}


The CF and NFC digestibility coefficients were increased $(P<0.05)$ when feeding on $\mathrm{R} 2$ compared with $\mathrm{R} 1$, while there was no significant difference between R1, and R3 or between R2, and R3. The ADL digestibility was higher $(P<0.05)$ when feeding on R2 than R1 and R3 or feeding on R3 than R1.

The DCP \% was increased $(P<0.05)$ when feeding on $R 2$ than $R 1$, or R3 or when feeding or R1, than R3.

The CNCPS predict values of ME, MP, and amino acid supplies from feeds, based on variations in DMI, feed composition and feed fiber characteristics. The analysis using CNCPS version 3.0 for the presented experimental rations could be summarized in table (9).

These parameters could explain the effects of the tested rations during the digestion trails. As shown in table (2), the DM intake was increased when feeding on R2 than R1, or R3 because the passage rate was higher when feeding on R2 $(8.5 \% / \mathrm{h})$ than feeding on R1 $(7.6 \% / \mathrm{h})$ or R3 $(7.8 \% / \mathrm{h})$. The digestibility trials shown in (table 3 ), revealed that $\mathrm{ME}(\mathrm{m} \mathrm{cal} / \mathrm{kg}$ ) was higher $(\mathrm{p}<10.05)$ when feeding on R2 $(2.96 \mathrm{Mcal} / \mathrm{kg})$ than feeding on R1 $(2.79 \mathrm{Mcal} / \mathrm{kg})$ or R3 $(2.77 \mathrm{Mcal} / \mathrm{kg})$. The prediction values for starch and sugar fermentations were increased when feeding on R2 than R1 or R3 in (table 9) and total microbial protein production $(\mathrm{g} / \mathrm{d})$ was affected with the same pattern. Concerning to NDF digestion, it was higher $(P<0.05)$ with R2 that feeding on R1 or R3 as shown in table (3), although the bacteria fiber fermentation was decreased when feeding on R2 or R3 than R1 as shown in table (9). The addition of buffer SB can improve fiber digestion by reducing the period of time during the day that ruminal PH is less than 6 ( Hutjens, 1992) Previous studies have shown that the use of sodium bicarbonate may result an increased rates of passage of the liquid phase of digesta (Bodes et al 2009). Stokes (1983) reported a quadratic increase in the dilution rate from the rumen of sheep fed diets supplemented with increasing levels of sodium bicarbonate. Whereas some authors have attributed the changes in rate of passage to a rise in acetic acid production ( Hadjipanoyiotou et al 1982), while others have suggested a mode of action related to a higher osmolality and water intake (Cooper et al, 1996).

\section{Rumen fermentation:}

The effects of feeding the three tested rations on some rumen liquor $(\mathrm{RL})$ parameters are presented in total (4).

The effects of feeding sodium bicarbonate (SB) on ruminal $\mathrm{pH}$ have been inconsistent in previously published literature. Hart and Polan (1984) reported for calves fed a corn based diet with added SB 1.5, 3.0 and $4.5 \%$ of DM.

There were no significant effects by dietary treatments, sampling time and their interactions on $\mathrm{pH}$ and buffering capacity $(\mathrm{BC})(\mathrm{ml}$ eq/ $100 \mathrm{ml} \mathrm{RL})$. The mean values for total VFA were higher $(P<0.05)$ with feeding on $R 1$ or $\mathrm{R} 2$ than R3. The mean values were 9.67, 9.88 and $8.05 \mathrm{ml}$ eq / $100 \mathrm{ml} \mathrm{RL}$ for $\mathrm{R} 1, \mathrm{R} 2$ and $\mathrm{R} 3$ respectively. The mean values for $\mathrm{NH}_{3}-\mathrm{N}$ concentration were decreased $(P<0.05)$ when feeding $R 2$ than $R 3$, and without significant effect with feeding R1. The mean values were 10.96, 9.36 and $13.5 \mathrm{mg} / 100$ $\mathrm{ml} \mathrm{RL}$ when feeding on $R 1, R 2$ and $R 3$, respectively. 
Ead, H. M. E.

There was no significant effect on the effective NDF (eNDF \%) when feeding on R1, R2 and R3. The wean values were $32.75,30.58$ and $28.51 \%$ for $\mathrm{R} 1, \mathrm{R} 2$ and $\mathrm{R} 3$ respectively.

Table (4): Effect of feeding experimental rations on some rumen liquor parameters at different time after feeding :

\begin{tabular}{|c|c|c|c|c|c|c|}
\hline Items & & R1 & R2 & R3 & +SEM & $P$ \\
\hline \multirow{4}{*}{$\mathrm{pH}$} & 0 & 7.78 & 7.75 & 7.73 & \multirow{4}{*}{0.236} & \multirow{4}{*}{0.9948} \\
\hline & 2 & 6.83 & 6.76 & 6.65 & & \\
\hline & 4 & 6.37 & 6.27 & 6.02 & & \\
\hline & 8 & 6.26 & 6.10 & 6.13 & & \\
\hline & means & 6.81 & 6.72 & 6.63 & 0.118 & 0.5704 \\
\hline \multirow{4}{*}{$\begin{array}{l}\text { Buffering capacity } \\
\text { (BC) } \mathrm{ml} \text { eq/100 ml }\end{array}$} & 0 & 13.33 & 13.93 & 13.17 & \multirow{4}{*}{0.809} & \multirow{4}{*}{0.9662} \\
\hline & 2 & 11.30 & 11.93 & 11.33 & & \\
\hline & 4 & 10.07 & 10.33 & 8.97 & & \\
\hline & 8 & 9.73 & 9.13 & 9.03 & & \\
\hline & means & 11.11 & 11.33 & 10.63 & 0.404 & 0.4609 \\
\hline \multirow{5}{*}{$\begin{array}{l}\text { Total VFA's } \\
(\mathrm{ml} \mathrm{eq} / 100 \mathrm{ml})\end{array}$} & 0 & 6.78 & 6.40 & 6.72 & \multirow{4}{*}{1.025} & \multirow{4}{*}{0.2527} \\
\hline & 2 & 11.08 & 10.08 & 8.27 & & \\
\hline & 4 & 10.43 & 12.72 & 7.77 & & \\
\hline & 8 & 10.37 & 10.30 & 9.35 & & \\
\hline & means & $9.67^{a}$ & $9.88^{a}$ & $8.05^{b}$ & 0.512 & 0.0339 \\
\hline \multirow{5}{*}{$\mid \begin{array}{l}\mathrm{NH}_{3}-\mathrm{N} \\
(\mathrm{mg} / 100 \mathrm{ml})\end{array}$} & 0 & 13.51 & 8.77 & 10.53 & \multirow{4}{*}{1.483} & \multirow{4}{*}{0.0266} \\
\hline & 2 & 9.65 & 7.54 & 16.14 & & \\
\hline & 4 & 11.40 & 10.09 & 12.03 & & \\
\hline & 8 & 9.29 & 12.11 & 13.51 & & \\
\hline & Means & $10.96^{\mathrm{ab}}$ & $9.63^{b}$ & $13.05^{a}$ & 0.741 & 0.0114 \\
\hline$\%$ eNDF* & & 32.75 & 30.58 & 28.51 & 4.192 & 0.7827 \\
\hline
\end{tabular}

a, b and $c$ : Means within the same raw with different superscripts are significantly different $(\mathrm{P}<0.05)$.

*\% eNDF $=(\mathrm{pH}-5.425) / 0.04229 \quad$ (Fox et al., 2000)

The rumen is the primary fermentations vat, muscular contractions aid in the constant mixing of feed materials' with bacteria laden fluids to promote fermentation and in the regurgitation of feed materials, which results in particle size reduction from chewing and stimulates copious production of saliva. Salivary bicarbonate ion is primarily responsible for maintaining only a slightly acid $\mathrm{pH}$ in the rumen (6.7 - 7.2 optimum), despite the tremendous amount of acids being produced during fermentation (Beharka et al 1998). The critical key to modeling rumen fermentations processes and applying this information's to practical dietary formulations understands what nutrients become available in the rumen. In forage fed animals, ruminal $\mathrm{pH}$ is generally near neutrality $(\mathrm{pH} \mathrm{7.0)}$ and is well buffered by bicarbonate and phosphate from saliva, proteins, forage cell walls and VFA (Russell and Hino, 1985). However, if the grain levels ingested exceed protozoal capacity to remove starch, protozoa populations will decline (Hristov et al , 2001) ; drastic increase in bacterial counts will occur, fermentation to VFA and lactic 
proceed and ruminal PH well decline (Mackie et al, 1978). No differences in ruminal $\mathrm{PH}$ in vivo due to buffer addition were observed, in agreement with other results reported by ( Khorasane and Kennelly, 2001; Kawas et al, 2007). Some authors have observed higher acetate and lower propionate molar proportions respectively, related, to greater fiber degradation (Van soest et al, 1991), and to an increased ruminal dilution rate and resulting washout of soluble carbohydrates form the rumen (Russell and Chow, 1993). Published results about changes in VEA production in response to SB administration are inconsistent, with some showing increases (Khorasani and Kennelly, 2001) and others decreases (James et al 1985) or no changes (Kawas et al 2007).

Although some studies have suggested that sodium bicarbonate can enhance the rate of ammonia utilization by the rumen bacteria (Newbold et al 1988), other researches working with cattle (Khorasani and Kennelly, 2001), have shown no effect an ruminal ammonia levels, which is in line with the results observed in this experiment.

Generally, dietary sodium bicarbonate acts as a buffer in the some way as endogenous sodium bicarbonate found in saliva, sodium bicarbonate works in an optimal pH range of 6.2 to 6.5. Not all studies have shown an increase in rumen $\mathrm{pH}$ in sodium bicarbonate treatment groups. There may be two reasons for this finding. Firstly, if the initial rumen $\mathrm{pH}$ was leas than 6.0 the buffering capacity of sodium bicarbonate is less. Secondly, studies with diets containing greater than $30 \%$ dry matter form forage show less pronounced effects by dietary buffers on rumen $\mathrm{pH}$ (Erdman, 1988). Currently, the Cornell Net carbohydrate and protein system (CNCPS) uses eNDF to adjust ruminal $\mathrm{pH}$ and passage rate (Sniffen et al, 1992). Factors other than particle size that influence eNDF include the degree of lignifications of the fiber, degree of hydration, and bulk density. The importance of eNDF can be seen in the reduced growth rate of structural carbohydrate - fermenting microorganisms and the reduction in total microbial yield when $\mathrm{pH}$ is lower than 6.2 (this being related to a dietary eNDF of $20 \%$ ).

\section{Blood parameters:}

Concerning blood metabolites, data in table (5) shows the values obtained when feeding the tested rations. There were no significant effects of feeding R1, or R2 or R3 on the blood parameters, but urea tended to increase with supplemented (SB) and glucose $(\mathrm{mg} / 100 \mathrm{ml}$ ) was increased with feeding on R3 than feeding on R1 or R2.

Table (5): Effect of experimental rations on some blood parameters :

\begin{tabular}{|l|c|c|c|c|c|}
\hline \multicolumn{1}{|c|}{ Items } & R1 & R2 & R3 & +SEM & $\boldsymbol{P}$ \\
\hline Total protein, g / 100 ml & 5.45 & 5.45 & 5.07 & 0.323 & 0.3982 \\
\hline Albumin, g / 100 ml & 3.47 & 3.00 & 2.72 & 0.191 & 0.0831 \\
\hline Globulin, g / 100 ml & 2.27 & 2.45 & 2.35 & 0.221 & 0.8508 \\
\hline Creatinine, mg / 100 ml & 6.58 & 0.72 & 0.71 & 0.123 & 0.6831 \\
\hline Urea-N , mg / 100 ml & 18.48 & 20.98 & 22.44 & 2.574 & 0.5763 \\
\hline GOT, IU / L & 58.3 & 51.6 & 59.6 & 7.125 & 0.7107 \\
\hline GPT, IU / L & 21.6 & 13.3 & 17 & 2.860 & 0.1998 \\
\hline Glucose, mg / 100 ml & 64.4 & 63.9 & 73.9 & 2.805 & 0.0774 \\
\hline
\end{tabular}


Ead, H. M. E.

Concerning blood metabolism, the presented data shows that the values were in the normal range of healthy animals as described by Mohamed and Selim (1999).

Body weight $(\mathbf{k g})$ and daily gain $(\mathbf{k g})$.

Table (6) shows the effect of feeding tested rations on ABW ( $\mathrm{kg}$ ) and average daily gain $(\mathrm{kg} / \mathrm{d})$. The average daily gain (ADG) from 7 to 8 month was increased $(P<0.05)$ with feeding on R1, than R2 and R3, however the average daily gain form 13 to 14 month was increased $(P<0.05)$ when feeding on R2 or R3 than R1 $(0.67,1.12$ and $0.99 \mathrm{~kg} /$ day for R1, R2 and R3 respectively). The mean values for ADG from 7 to 15 month were $0.62,0.69$ and $0.66 \mathrm{~kg} / \mathrm{d}$ when feeding with $\mathrm{R} 1, \mathrm{R} 2$, and $\mathrm{R} 3$ respectively). There was no significant effect on the production efficiency $(18.74,16.77$ and $18.85 \%$ for $\mathrm{R} 1, \mathrm{R} 2$ and $\mathrm{R} 3$ respectively) as show in table (7), but the economic efficiency was decreased (5.88\%) when feeding on R2 than R1 or R3 (15.13 and $14.71 \%$ respectively), but without significant effects as show in table (8).

Actual age and birth date are very important. Steers and heifers are placed on feed between ages of 6 to 10 months. Most calves are weaned at about 6 to 7 month old (Boleman et al, 2001) .

During the last decade the interest of meat producers has shifted from obtaining maximum growth of the animal to productions of lean meat and an increase in the efficiency of nitrogen utilization (Gerrets et al, 1997) . Depending on dietary treatment, average daily gain of the empty body varied between 640 and $1340 \mathrm{~g} / \mathrm{d}$ and 420 and $1370 \mathrm{~g} / \mathrm{d}$ for the growth ranges of $80-160$ and $160-240 \mathrm{~kg}$ live weight, respectively. The average daily gain of the present results were $0.60,0.47$ and $0.47 \mathrm{~kg} / \mathrm{d}$ when feeding R1. R2, R3, respectively from 7 to 10 months old, and $0.63,0.80$ and $0.80 \mathrm{~kg} / \mathrm{d}$ when feeding the same rations from 11 to 15 month, old. The production efficiency results were $18.74,16.77$ and $18.85 \%$, while the economic efficiency results were $15.13,5.88$ and $14.71 \%$ when feeding $\mathrm{R} 1, \mathrm{R} 2$ and $\mathrm{R} 3$ rations, respectively. Ingested true protein may either be degraded by ruminal microorganisms, or may escape degradation and pass to the lower gut to be digested or excreted in the faces. The amount of true protein that escapes degradation may vary considerably, on escape rate of $40 \%$ for the dietary protein probably represents an acceptable average. The remaining $60 \%$ of dietary protein is degraded almost entirely to $\mathrm{NH}_{3}$ ( Satter and Rofflei, 1977). Feeds high in TDN are more fermentable than those low in TDN. Therefor more $\mathrm{NH} 3-\mathrm{N}$ can be utilized when feeds high in TDN are needed. Mean ruminal $\mathrm{NH}_{3}$ concentrations was found to be positively related to percent $\mathrm{CP}$ in the ration dry matter. As dietary $\mathrm{CP}$ increased above $13 \%$ (DM basis), ruminal $\mathrm{NH}_{3}$ increased rapidly and was in excess of $5 \mathrm{mg} \mathrm{NH}-\mathrm{N} / 100$ rumen liquor. Thus, when ration CP content is greater then $13 \%$ more $\mathrm{NH}_{3}$ is present in the rumen than can be converted to microbial protein.

The following multiple regression equation, which considers both $\mathrm{CP}$ and TDN was found to improve the precision of predicting mean rumnial $\mathrm{NH}_{3}$ $\mathrm{N}$ concentration (Satter and Rofflei, 1977).

$$
Y=38.73-3.04 x_{1}-0.490 x_{2}+0.171 x_{1}{ }^{2}+0.0024 x_{2}{ }^{2}
$$

Where $\mathrm{Y}=$ Ruminal $\mathrm{NH}_{3}-\mathrm{N} / 100 \mathrm{ml}$ rumen fluid

$\mathrm{X} 1=\% \mathrm{CP}$ in ration $\mathrm{DM}$

$X 2=\%$ TDN in ration DM 
Table (6): The effect of feeding tested rations on the average body weight $(\mathrm{kg})$ and daily gain $(\mathrm{kg})$.

\begin{tabular}{|c|c|c|c|c|c|c|c|c|c|c|}
\hline \multirow{2}{*}{ Items } & \multicolumn{5}{|c|}{ BW } & \multicolumn{5}{|c|}{ ADG } \\
\hline & R1 & R2 & R3 & \pm SEM & $\boldsymbol{P}$ & R1 & R2 & R3 & +SEM & $P$ \\
\hline $\begin{array}{l}\text { Initial } \\
(7 \mathrm{mo})\end{array}$ & 112 & 106 & 115 & 4.152 & 0.356 & - & - & - & - & - \\
\hline 7-8 mo & 135 & 118 & 126 & 4.593 & 0.074 & $0.77^{\mathrm{a}}$ & $0.40^{\mathrm{b}}$ & $0.39^{b}$ & 0.046 & 0.0003 \\
\hline $8-9 \mathrm{mo}$ & 149 & 137 & 147 & 6.430 & 0.420 & 0.47 & 0.65 & 0.69 & 0.084 & 0.1929 \\
\hline $9-10 \mathrm{mo}$ & 165 & 149 & 157 & 7.238 & 0.3098 & 0.54 & 0.37 & 0.33 & 0.072 & 0.1566 \\
\hline $10-11 \mathrm{mo}$ & 194 & 186 & 195 & 7.075 & 0.6411 & 0.97 & 1.25 & 1.25 & 0.103 & 0.1375 \\
\hline $11-12 \mathrm{mo}$ & 206 & 198 & 206 & 7.606 & 0.7089 & 0.39 & 0.38 & 0.40 & 0.042 & 0.9567 \\
\hline $12-13 \mathrm{mo}$ & 226 & 221 & 227 & 7.326 & 0.8416 & 0.67 & 0.77 & 0.75 & 0.040 & 0.2139 \\
\hline $13-14 \mathrm{mo}$ & 246 & 255 & 257 & 8.681 & 0.6739 & 0.67 & 1.12 & 0.99 & 0.091 & 0.0202 \\
\hline $14-15 \mathrm{mo}$ & 261 & 271 & 274 & 9.336 & 0.6051 & 0.48 & 0.47 & 0.57 & 0.067 & 0.6918 \\
\hline $\begin{array}{l}\text { Mean 7- 15 } \\
\text { mo }\end{array}$ & - & - & - & - & - & 0.62 & 0.69 & 0.66 & - & - \\
\hline
\end{tabular}

a, b and c : Means within the same row with different superscripts are significantly different $(\mathrm{P}<0.05)$.

Table (7): Production efficiency of growing calves fed the experimental rations :

\begin{tabular}{|l|c|c|c|c|c|}
\hline \multicolumn{1}{|c|}{ Items } & R 1 & R 2 & R 3 & SEM & $\boldsymbol{P}$ \\
\hline $\mathrm{DMl} \mathrm{kg} \mathrm{/} \mathrm{d}$ & 7.56 & 7.98 & 7.5 & 0.389 & 0.5626 \\
\hline ME Mcal / kg & 2.79 & 2.96 & 2.77 & 1.042 & 0.1953 \\
\hline ME Mcal / d & 21.14 & 23.63 & 20.83 & 1.042 & 0.1953 \\
\hline NE Pcal /d & 8.96 & 10.02 & 8.83 & 0.442 & 0.1952 \\
\hline Live weight (kg) & 266 & 260 & 264 & 6.179 & 0.7636 \\
\hline ADG kg / d & 0.66 & 0.66 & 0.66 & 0.022 & 0.9789 \\
\hline Retained energy ( Mcal /d ) & 1.67 & 1.67 & 1.66 & 0.081 & 0.9862 \\
\hline Production efficiency & 18.74 & 16.77 & 18.85 & 0.669 & 0.1213 \\
\hline
\end{tabular}

Table (8): Economic efficiency of the experimental ration :

\begin{tabular}{|l|c|c|c|c|c|}
\hline \multicolumn{1}{|c|}{ Items } & R 1 & R 2 & R 3 & SEM & $\boldsymbol{P}$ \\
\hline Price / kg fresh ( LE ) & 8.59 & 9.35 & 8.5163 & 0.572 & 0.6545 \\
\hline ADG kg / d & 0.66 & 0.66 & 0.66 & 0.022 & 0.9789 \\
\hline Price of daily gain ( LE ) & 9.9 & 9.9 & 9.9 & 0.341 & 0.97989 \\
\hline Profit ( LE ) & 1.30 & 0.55 & 1.27 & 0.439 & 0.5775 \\
\hline Economic efficiency \% & 15.13 & 5.88 & 14.71 & 0.270 & 0.6221 \\
\hline
\end{tabular}

Market price pt. $/ \mathrm{kg}$ fresh of : concentrate feed mixture $=1.4 ; \quad$ Clover hay $=70$ $\mathrm{Kg}$ body weight gain $=1500$

* was calculated according to the DMI from all ingredients during the digestion trails.

The predicted ruminal $\mathrm{NH}_{3}-\mathrm{N}$ concentrations when feeding the presented tested rations were $11.63,10.47$ and $10.34 \mathrm{mg} / 100 \mathrm{ml} \mathrm{RL}$ with feeding R1, R2 and R3, respectively. The corresponding actually determined mean values were 10.96, 9.63 and $13.05 \mathrm{mg} / 100 \mathrm{ml} \mathrm{RL}$ (table 4). The values were almost identical for the control ration. However, the predicted values for the tested rations including SB were somewhat higher than those determined, since the prediction system relies only on CP and TDN with no account for SB. 
Ead, H. M. E.

Remond et al (2002) observed significant net influx of $\mathrm{N}$ into the rumen when ruminal $\mathrm{NH}_{3}-\mathrm{N}$ fell below $9.5 \mathrm{mg} / 100 \mathrm{ml}$, which would be expected to occur at approximately $14 \%$ dietary protein.

Concepting to the amino acids composition of the tested rations, the AAs composition were less than the requirements except for tryptophan. The mean balance AA values (\% of requirement) were $70.45,68.14$ and 71.73 with feeding on R, R2, R3, respectively as shown in table (9). Proteins are composed of 20 amino acids, many of which the calf can synthesize in adequate amounts to meet its needs. But several amino acids must be consumed in the diet because the calf cannot synthesize these amino acids. These amino acids are lysine, histidine, leucine, iso- leucine, valine, methionine, threonine, tryptophan, tyrosine and phenylalanine. Amino acid imbalances result in reduced animal performance (Abe et al, 2001).

Table (9): The metabolizable energy (ME), metabolizable protein (MP), microbial growth, passage rates and amino acids of the tested rations :

\begin{tabular}{|l|c|c|c|}
\hline \multicolumn{1}{|c|}{ Items } & R1 & R2 & R3 \\
\hline DMI ( kg/d) & 7.6 & 8 & 7.5 \\
\hline MEI Mcal / d & 14.9 & 15.5 & 14.2 \\
\hline CP \% & 17.7 & 17.5 & 17.1 \\
\hline MP from bacteria ( g/d ) & 306 & 310 & 291 \\
\hline MP from UIP ( g/d ) & 421 & 461 & 402 \\
\hline Fiber Fermentation (g/d) & 81.6 & 73.1 & 76.8 \\
\hline Sugar Fermentation (g/d) & 274 & 276.8 & 267 \\
\hline Starch Fermentation (g/d) & 640 & 475.8 & 431.7 \\
\hline Total microbial protein (g/d) & 815 & 825 & 775 \\
\hline Total passage rate (\%/h) & 7.6 & 8.5 & 7.8 \\
\hline Balance AA ( \% of requirement ) & \multicolumn{3}{|l|}{} \\
\hline Methionine. & 61 & 59 & 62.1 \\
\hline Lysine & 57.7 & 55.8 & 58.8 \\
\hline Arginine & 47.5 & 46 & 48.4 \\
\hline Threonine & 64.2 & 62.1 & 65.4 \\
\hline Leucine & 49.9 & 48.3 & 50.7 \\
\hline Isoleucine & 91.6 & 88.6 & 93.2 \\
\hline Valine & 67.7 & 65.5 & 68.9 \\
\hline Histidine & 49.1 & 47.5 & 50.0 \\
\hline Phenylalanine & 65.9 & 63.7 & 67.1 \\
\hline Tryptophan & 149.9 & 144.9 & 152.7 \\
\hline Total AAL \% of reqeumnt & 70.45 & 68.14 & 71.73 \\
\hline
\end{tabular}

\section{Conclusion:}

The experimental diets were found to affect ruminal $\mathrm{pH}$, volatile fatty acid production, rate of passage, voluntary feed intake and nutrient digestibility. In the present study, dry matter intake, nutrient digestibility and feeding values were increased using a lower dose of sodium bicarbonate (1.5 $\%$ of DM) . However the mode of action of this buffer additive remains 
unclear. Further studies are necessary to test the effect of SB to diets of higher proportions of concentrates which are usually fed during fattening period rather than growing period.

\section{REFERENCES}

Abe, M., Iriki, T., Kaneshige, K., Kuwashima, K., Watanable, S., Sato, H. and Funaba, M. (2001). Adverse effects of excess lysine in calves. J. Anim. Sci., 78:2722 .

AOAC (1990). Association of Official Analytical Chemists. Official Methods of Analysis. 15th Ed., Washington DC .

Beharka, A.A., Nagaraja T.G. and Morril, J.L. (1998). Effects of form of the diet on anatomical, microbial and fermentative development of the rumen of neonatal calves. J.Dairy Sci., 81:1946.

Bodas, R., Frutos, P., Giraldez, F.J. Hervas, G. and Lopez, S. (2009) Effect of sodium bicarbonate supplementation on feed intake, digestibility, digesta kinetics, nitrogen balance and ruminal fermentation in young fattening lambs. Spanish Journal of Agriculture Research, 7(2): 330.

Boleman, L.L., Herd, D.B. and Boleman, C.T. (2001). Managing beef cattle for show Agrilife Extension, Texas A\&M system.

Britton, R.A. and Stock, R.A. (1986). Acidosis, rate of starch digestion and intake. Page 125-137 in symposium proceedings: Feed intake by beef cattle. Oklahoma State University.

Burrell, W. C. (2000). Managing forage resources for efficient beef production. Utah Cattlemen 's Association, Brigham Young University, Utah State University.

Calsamiglia, S.; M.D. Stern and J.L. Firkins (1995). Effects of protein source on nitrogen metabolism in continuous culture and intestinal digestion in vitro. J. Anim. Sci., 73: 1819.

Conway, E.F. (1957). Microdiffusion Analysis and Volumetric Error. Rev. Ed. Lock wood, London.

Coopper, S.D.B. Kyriazakis, I., and Oldham, J.D. (1996). The effects of physical form of feed, carbohydrate source and inclusion of sodium bicarbonate on the diet selections in sheep. J.Anim. Sci., 74:1240.

Duncan, D.B. (1955). Multiple Range and Multiple F Test. Biometrics, 11:10.

Ead, H.M.E. and Eman H.M. Maklad (2006). Influence of feeding different levels of soybean meal in growing Friesian calves rations on: 1productive performance after weaning. J. Agric. Sci. , Mansoura Univ., 31(3) : 1335.

Erdman, R.A. (1988). Dietary buffering requirements of the lactating dairy cow: A review. J. Dairy Sci. 71:3246.

Fox, D. G. ; T. P. Tylutki; M. E. Van Amburgh; L. E. Chase; A. N. Pell; T. R. Overton; L. O. Tedeschi; C. N. Rasmussen and V. M. Durbal (2000). The net carbohydrate and protein system for evaluating herd nutrition and nutrient excretion. Animal Science Mimeo 213, Department of animal science, Cornell university, 130 Morrison Hall, Ithaca, New York 14853. 
Ead, H. M. E.

Gerrits, W.J.J., Dijkstra, J. and France, J. (1997). Description of a model integrating protein and energy metabolism in preruminant calves. American Society for Nutritional Sciences.

Ghoneim, A. (1967). Animal Nutrition, Principles and Feeding-stuffs $2^{\text {nd }}$ Edt. Anglo.. Egyptian Library, University. (Arabic Text Book).

Ghorbani, G.R., Jackson, J.A. and Hemken, R.W. (1989). Effects of sodium bicarbonate and sodium sesquicarbonate on animal performance, ruminal metabolism and acid-base status. J. Dairy Sci., 72:2039.

Gornall, A. C., Bard will and M. M. David (1949). Determination of total serum protein. J. Biol. Chem., 177: 751.

Hadjipanayiotou, M., Harrison, D.G. and Armstrong, D.G. (1982). The effects upon digestion in sheep the dietary inclusion of additional salivary salts. J. Sci. Food Agri., 33:1057.

Hart, S.P. and Doyle, J.J. (1985). Adaptation of early weaned lambs to high concentrate diets with three grain sources, with or without sodium bicarbonate. J. Anim. Sci., 61:975.

Hart, S.P. and Polan, C.E. (1984). Effects of sodium bicarbonate and disodium phosphate on animal performance, ruminal metabolism, digestion and rate of passage in ruminating calves. J. Dairy Sci., 67:2356.

Hill, P. G. and T. N. Wells (1983). Ann. Clin Biochem., 20: 265.

Hoover, W. H. and Stokes, S. R. (1991). Balancing carbohydrates and proteins for optimum rumen microbial yield. J. Dairy Sci., 74: 3630.

Hristov, A.N. , Ivan, M. , Rode, L.M. and McAllistor, T.A. (2001). Fermentation Characteristics of luminal ciliate protozoal population in cattle fed medium or high concentrate barely-based diets. J. Anim. Sci., 79:515.

Hunter, R. D., Drouillard, J. S. and Titgemeyer, E. C. (1999). Effect of level of non-enzymatically browned soybean meal in limited fed, grain sorghum diets for growing fibers. Kansas State University Agricultural Experiment Station and Cooperative Extension Service.

Hutjens, M.F. (1992) Selecting feed additives. In Large Dairy Herd Management (Van Horn, H.H. and Wilcox, C.J., eds. ), PP. 309317.American Dairy Science Association, Savoy, IL.

James, L. G., Wohlt, J. E. (1985). Effect of supplementing equi-valent cation amounts from $\mathrm{NaCl}, \mathrm{MgO}, \mathrm{NaHCO}_{3}$ and $? \mathrm{CaCO}_{3}$ on nutrient utilization and acid-base status of growing dorset lams fed high concentrate diets. J Anim. Sci., 60, 307.

Kawas, J.R., Garcia-Castillo, R., Fimbres-Durazo, H., Garza- Cazares, F., Hernandez-Vidal, J.F.G., Olivares-Saenz, E. and Lu, C.D. (2007). Effects of sodium bicarbonate and yeast on nutrient intake, digestibility and ruminal fermentation of light-weight lambs fed finishing diets. Small ruminal Res., 67: 149.

Khorasani, G.R. and Kennelly, J.J. (2001). Inflluence of carbohydrate source and buffer on lumen fermentation characteristics, milk yield and milk consumption in late lactation Holstein cows. J. Dairy Sci., 84 : 1707.

Loerch, S.C. (1995). Limit feeding strategies for backgrounding and finishing cattle. Ohio Cattleman, March-April P.51. 
Loerch, S.C., Smith,F.E. and FLuharty ,F.L. (1995). effects of programming rate of gain on feedlot performance of cattle. Ohio Beef cattle Res. Ind. Rpt. The Ohio state University. P.48.

Mackie, R.I., Gilchrist, F.M.C., Robberts, A.M., Hannal, P.E., and Schwartz, H.M. (1978). Microbiological and chemical changes in the rumen during the stepwise adaptation of sheep to high concentrate diets. J. Agric, Sci. camb., 90:241.

Mees, D.C., Merchen, N.R., Mitchel, C.J. (1985). Effects of sodium bicarbonate on nitrogen balance, bacterial protein synthesis and sites of nutrient digestion in sheep. J. Anim. Sci., 61:985.

Mohamed, H.A and Selim, H.M. (1999). Hand Book of Veterinary Internal Medicine. Department of Animal Medicine, Faculty of Veterinary Medicine, Zagazige Univ.

National Research Council (NRC), (2001). Nutrient Requirements of Dairy Cattle, $7^{\text {th }}$ rev. ed. National Academy Sci., Washington, DC.

Newbold, C.J., Thomas, P.C., and Chamberlain, D.G. (1988). Effect of dietary supplements of sodium bicarbonate on the utilization of nitrogen in the rumen of sheep receiving a silage based diet. J. Agric. Sci., 110,383.

Nickolson, J.W.G.; M.M. Cunningham and D.W. Friend (1963). The addition of buffers to ruminant rations. 4- The effect of additions of sodium bicarbonate, sodium propionate, limestone and cod liver oil on inter rumen environment. Canadian J. Anim. Sci., 42: 309.

NRC (National Research Council), (1996). Nutrient Requirements of beef Cattle $\left(7^{\text {th }}\right.$ ed.) National Academy Press, Washington, DC.

O' Connor, J.D. Sniffen, C.J. Fox, D.G. and Chalupa, W. (1993). A net carbohydrate and protein system for evaluating cattle diets. IV. Predicting amino acid adequacy. J.Anim. Sci., 71:1298.

Overton, T. (1999). "Research Feature" Total Dairy Nutrition, Vol, 1, No, 2 April1999.

Owens, F.N., Secrist, D.S., Hill, W.J. and Gill, D.R. (1998). Acidosis in cattle : a review. J.Anim. Sci., 76:275.

Paton, L.J. (2005). Effects of sodium bicarbonate on reducing acidosis in cattle. M.Sc. Thesis, Faculty of Graduate Studies, The University of British Columbia.

Patton . J. and Crouch, S. R. (1977). Spectrophotometric and kinetics investigation of the Berthelot reaction for the determination of ammonia. Anal. Chem. 49: 464.

Pitt, R.E., Van Kessel, J.S., Fox, D.G., Barry, M.C., and Van Soest, P.J. (1996). Prediction of ruminal volatile fatty acids and $\mathrm{pH}$ within the net carbohydrate and protein system. J.Anim, Sci., 74:226.

Poor, M. H., Moore, J. A., Eck, T. P., Swirgle, R. S. and Theurer, C. B. (1993). Effect of fiber source and ruminal starch degradability on site and extent of digestion in dairy cows. J. Dairy Sci., 76: 2244.

Reitman, A. and S. Frankel (1957). A colorimetric method of determination of S.GOT and S.GPT. American J. of Clinical Pathology, 28: 56.

Remond, D., Noziere, P. and Poncet, C. (2002). Effect of time of starch supply to the rumen on the dynamics of urea and ammonia net flux across the rumen wall of sheep. Anim. Res., 51:3 . 
Ead, H. M. E.

Russell, J. B., O'Connar, J. D., Fox, D. G., Van Soest, P.J. and Sniffen, C.J. (1992). A net carbohydrate and protein system for evaluating cattle diets, 1. Ruminal fermentation. J. Animal Sci., 70:3551.

Russell, J.B. and Chow, J.M. (1993). Another theory for the action of ruminal buffer salts: decreased starch fermentation and propionate production. J. Dairy Sci., 76:826.

Russell, J.B. and Hina, T.(1985). Regulation of lactate production in streptococcus bovis a spiraling effect that contributes to rumen acidosis. J. Dairy Sci., 68:1712.

Russell, J.B., Young, A.W. and Jorgensen, N.A. (1980). Effects of sodium bicarbonate and limestone additions to high grain diets on feedlot performance and ruminal and fecal performance in finishing steers. J. Anim, Sci., 51:996.

SAS Institue (1994). SAS / STAT R User's Guide : Statistics. Ver. 6.04, Fourth Edition SAS Institute Inc, Cary, NC.

Satter, L.D. and Rofflei, R.R. (1977). Protein requirement and non protein nitrogen utilization. Trop. Anim. Prod., 2: 3.

Schneider, B.H. and W.P. Flatt (1975). The Evaluation of Feeds Through Digestibility Experiments. The University of Georgia Press Athens, 30602.

Schroeder, J.W. (1996). Quality forage for maximum production and return . NDSU Extension service, North Dakota State University .

Schredes, P. (2002). Feeding and Razing the Show Steer. OSU Livestock and Riparian, Linn/ Benton/ Lan Countries No. LR 103.

Sniffen, C.J., O'Connor, J.D., Van Soest, P.J., Fox, D.G. and Russel, J.B. (1992). A net carbohydrate and protein system for evaluating cattle diet. II. Carbohydrate and protein availability. J.Anim Sci., 70:3562.

Stock, R. and Mades, T. (1985). Food additives for beef cattle. University of Nebraska- Lincoln. NeGuide. G 85-761.

Stokes, M.R. (1983). Effect of sodium bicarbonate of rumen turnover in frequently fed sheep. Can. J. Anim. Sci., 63:721.

Teuscher, A. and R. Richterich (1971). Schweiz. Med. Woschr. 101: 345.

Trenkle, A. and. Barrett K (2003). Feedlot performance of cattle program supplemental protein. Beef research Reported-lowa state University, AS. 1832.

Tripathi, M.K., Santra, A., Chaturvedi, O.H. and Karim, S.A. (2004). Effect of sodium bicarbonate supplementation on ruminal fluid $\mathrm{PH}$, feed intake, nutrient utilization and growth of lambs fed high concentrate diets. Anim. Feed Sci., Technol 111, 27.

Ullmann, K. (1976). Bonitz. Med. Labor., 29: 137.

Van Keulen, J. and B.A.Young (1977). Evaluation of acid insoluble ash as a natural marker in ruminant digestibility studies. J.Anim. Sci., 44: 282.

Van Soest, P.J., Robertson, J.B., and Lewis, B.A. (1991). Methods for dietary fibers, neutral detergent fibers and nonstarch polysaccharides in relation to animal nutrition. J.Dairy Sci., 74: 3583.

Van Soset, P. J. (1982). Nutritional Ecology of the Ruminant. O \& B Books Inc., Corvallis, Oregon, USA, pp 1. 
Warner, A.C.I. (1964). Production of volatile fatty acids in the rumen, methods of measurements. Nutr. Abst.\& Rev., 34. 339.

Winger, H., Zobell, D.R. and Olson, K.C. (2006). Supplementaion of energy and protein for beef cattle, A literature Reviews. Utah State University, Cooperative extension.

Yohn, C. W.. (2007). 2007 Drought Management Handbook. West Virginia Unversity, Extension Service.

Zinn, R.A. (1991). Comparative feeding value of steam flaked sorn and sorghum in finishing diets supplemented with or without sodium bicarbonate. J. Anim. Sci., 69: 905.

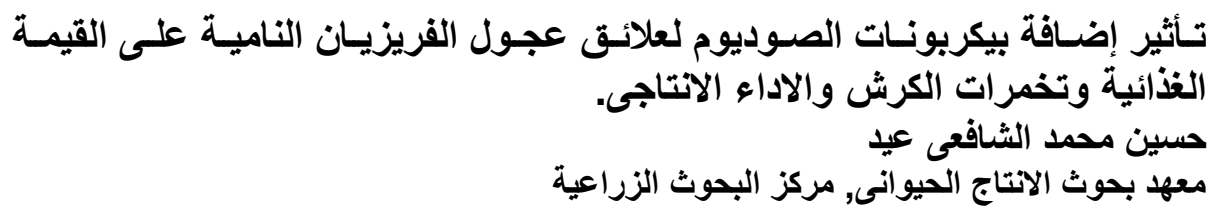

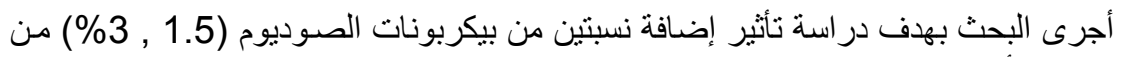

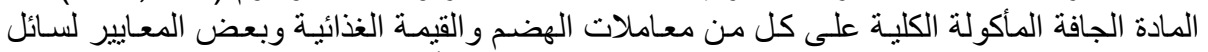

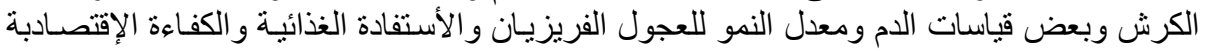

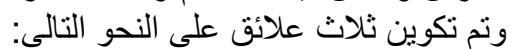

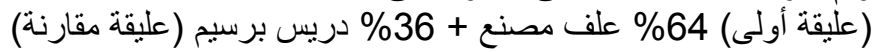

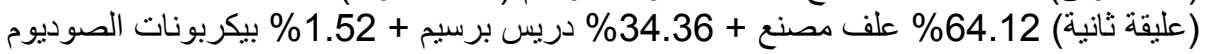

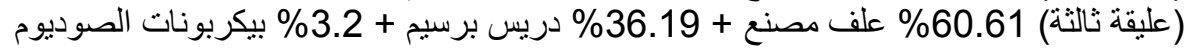

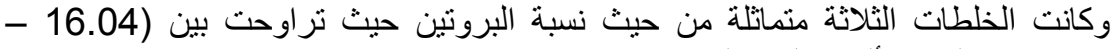
16.57\%) ومستخلص الألياف المتعادلة (43.74 - 43.

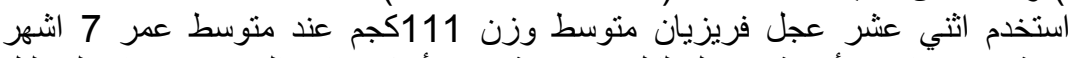

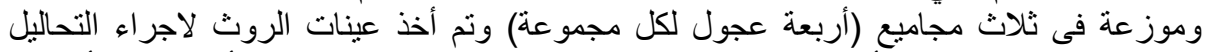

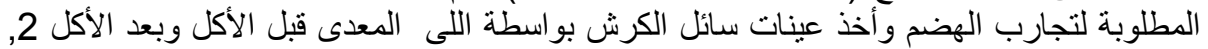

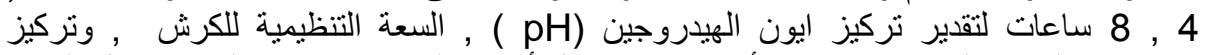

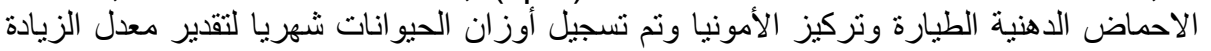

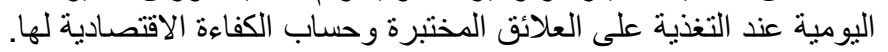

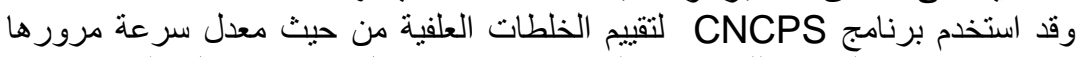

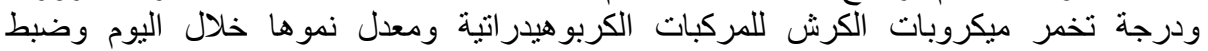

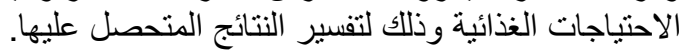

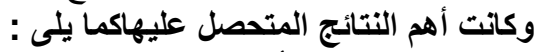

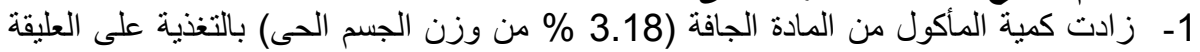

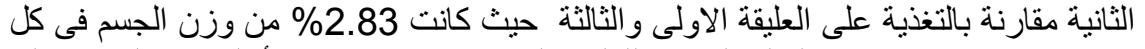

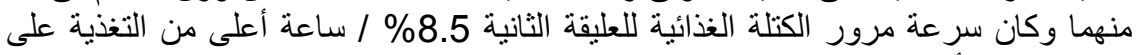

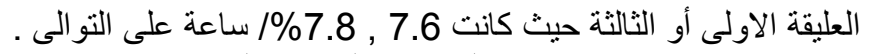

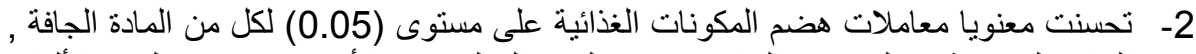

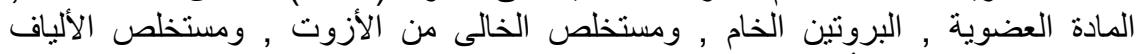

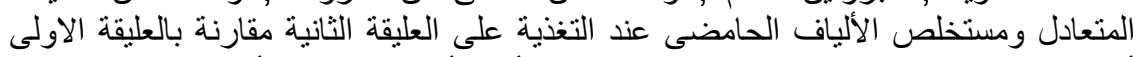

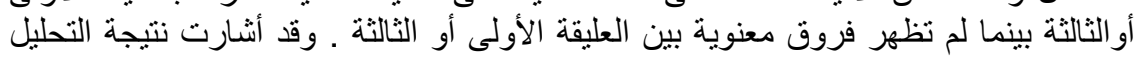




\section{Ead, H. M. E.}

الغذائى الى زيادة البروتين المتكون بالتغذية على العليقة الثانية (815 (825 جم / يوم) مقارنة

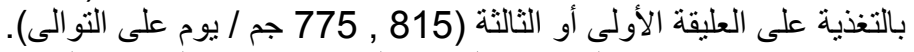

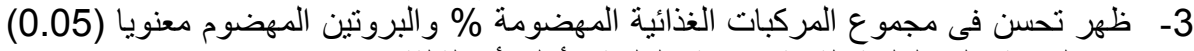

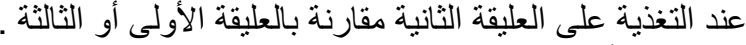

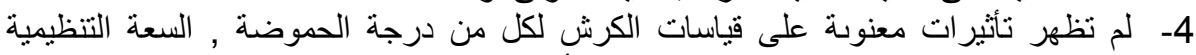

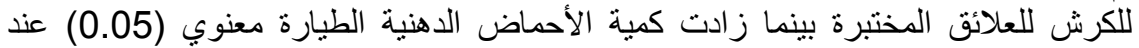

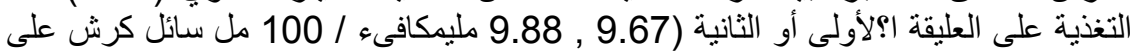

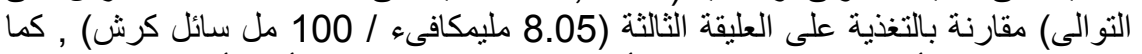

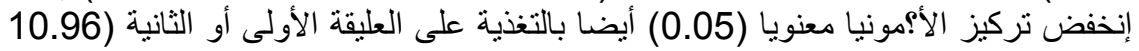

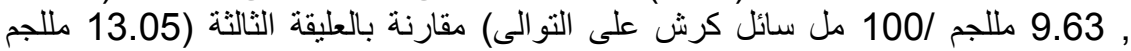

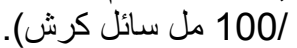

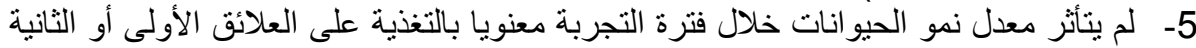

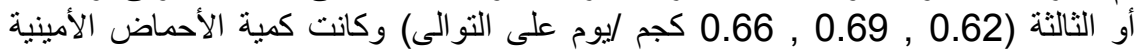

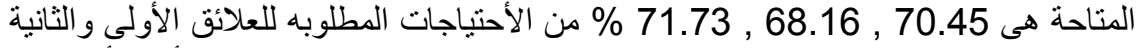

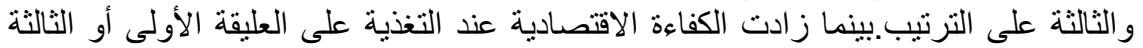

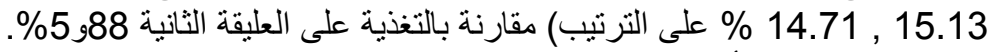

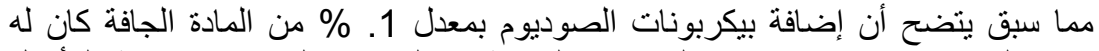

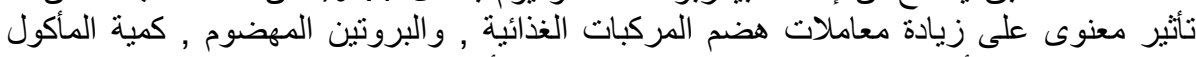

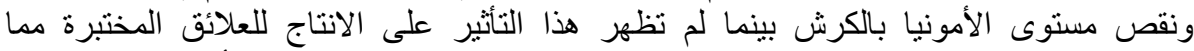

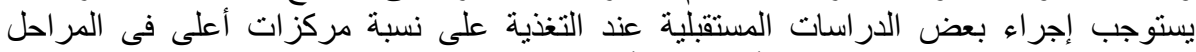
المتقدمة من النمو مع توفير بعض الأحماض الأمينية الضرورية للانتاج.

$$
\text { كلية الزراعة الزراعة - جامعة عين شنصورة }
$$

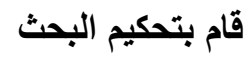

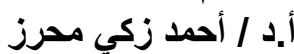

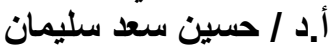

